\title{
REVIEW
}

\section{Pathobiology and genetics of adrenocortical carcinoma}

\author{
James F H Pittaway and Leonardo Guasti
}

Centre for Endocrinology, William Harvey Research Institute, Barts and the London School of Medicine and Dentistry, Queen Mary University of London, London, UK

Correspondence should be addressed to J F H Pittaway: jfhpittaway@doctors.org.uk

\begin{abstract}
Adrenocortical carcinoma (ACC) is a rare malignancy with an incidence worldwide of 0.7-2.0 cases/million/year. Initial staging is the most important factor in determining prognosis. If diagnosed early, complete surgical resection +/- adjuvant treatment can lead to 5 -year survival of up to $80 \%$. However, often it is diagnosed late and in advanced disease, 5 -year survival is $<15 \%$ with a high recurrence rate even after radical surgery. The mainstay of adjuvant treatment is with the drug mitotane. Mitotane has a specific cytotoxic effect on steroidogenic cells of the adrenal cortex, but despite this, progression through treatment is common. Developments in genetic analysis in the form of next-generation sequencing, aided by bioinformatics, have enabled high-throughput molecular characterisation of these tumours. This, in addition to a better appreciation of the processes of physiological, homeostatic self-renewal of the adrenal cortex, has furthered our understanding of the pathogenesis of this malignancy. In this review, we have detailed the pathobiology and genetic alterations in adrenocortical carcinoma by integrating current understanding of homeostasis and self-renewal in the normal adrenal cortex with molecular profiling of tumours from recent genetic analyses. Improved understanding of the mechanisms involved in self-renewal and stem cell hierarchy in normal human adrenal cortices, together with the identification of cell populations likely to be co-opted by oncogenic mutations, will enable further progress in the definition of the molecular pathways involved in the pathogenesis of ACC. The combination of these advances eventually will lead to the development of novel, effective and personalised strategies to eradicate molecularly annotated ACCs.
\end{abstract}

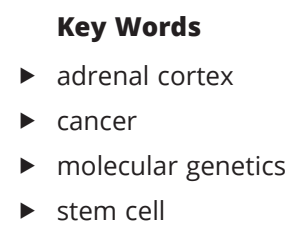

Journal of Molecular Endocrinology (2019) 62, R105-R119

\section{Introduction}

Adrenocortical carcinoma (ACC) is a rare malignancy with an incidence worldwide of $0.7-2.0$ cases/million/year (Kebebew et al. 2006, Kerkhofs et al. 2013). It can occur at any age and has a bimodal incidence, predominantly affecting adults in their 40-50s and children aged 1-5 years (Wajchenberg et al. 2000). ACC is a heterogeneous condition with a varied presentation. In adults, $40-60 \%$ of patients present with signs and symptoms of adrenal steroid hormone excess. In those without clinical evidence of hormonal excess, approximately half will present with features of abdominal mass effect and half will be discovered incidentally through imaging for unrelated medical conditions (Fassnacht \& Allolio 2009, Else et al. 2014). In children, hormonal excess is a more 
common presentation, occurring in up to $90 \%$ of cases (Michalkiewicz et al. 2004).

Initial staging is the most important factor in determining prognosis. The staging system proposed by the European Network for the Study of Adrenal Tumors is widely used and is reliable in predicting prognosis (Fassnacht et al. 2009, Lughezzani et al. 2010). Tumours that are confined to the adrenal gland are defined as stage 1 (if $<5 \mathrm{~cm}$ ) and stage 2 (if $>5 \mathrm{~cm}$ ). Stage 3 disease has features of local disease spread, including infiltration of surrounding tissue, local vascular tumour thrombus and positive regional lymph nodes. Stage 4 disease refers to patients with distant metastatic spread.

Five-year survival is as high as $81 \%$ in those presenting with stage 1 disease. However, approximately half of the patients present after the disease has breached the adrenal capsule and 5-year survival drops to 50\% in stage 3 and as low as $13 \%$ in those with stage 4 (Fassnacht et al. 2009, Else et al. 2014).

The histopathological diagnosis of ACC, and importantly its distinction from benign adrenal adenomas, cannot be made on single morphological parameters alone. The Weiss score has widely been used since its introduction in 1984 to diagnose ACC (Weiss 1984). It consists of nine histopathological parameters relating to tumour invasion, tumour cell properties, tumour structure and mitotic rate to predict the malignant potential of the tumour. It has subsequently been modified to the Weiss Revised Index, consisting of only five parameters with greater weight on mitotic rate and tumour cell type (Aubert et al. 2002). Despite the overall good predictive value of this scoring method, it performs less well in cases with borderline features, tumours of different cell types (myxoid, oncocytic and sarcomatoid) (Pohlink et al. 2004, Papotti et al. 2011) as well as in children, where the Wieneke criteria are more predictive of the clinical outcome (Wieneke et al. 2003). In order to address this, the Helsinki Score has been developed which in addition to the morphological parameters of the Weiss score, includes immunohistochemical evidence of proliferation in the form of Ki67 staining (Pennanen et al. 2015). Ki67 has been independently shown to be a good predictor of malignant potential and have a major prognostic role in ACC (Beuschlein et al. 2015). The Helsinki Score has also been validated as a marginally superior prognostic tool for ACC compared to Weiss score with notably a more useful role in myxoid variant tumours (Duregon et al. 2017).

In addition to Ki67, there has been a lot of interest in defining new immunohistochemical markers to aid in the prognosis of ACC (reviewed in Lalli \& Luconi 2018).
Most recently, the cytoskeletal remodelling factor VAV2 has been shown to improve prognostic stratification in ACC when combined with Ki67 (Sbiera et al. 2017). Increased VAV2 expression is independently correlated with shorter disease-free and overall survival. It may have an advantage over Ki67 as its expression is more homogenous in tissues studied. VAV2 expression is increased by steroidogenic factor-1 (SF1) in a dose-dependent manner and drives cell invasion in ACC (Ruggiero et al. 2017). SF1 is another immunohistochemical marker whose increased expression in ACC is correlated with worse disease-free and overall survival (Sbiera et al. 2010, Duregon et al. 2013).

Currently, surgical resection offers the only hope of a curative intervention in ACC. The outcomes are far improved when this is undertaken in specialist centres with extensive experience of these operations (Bilimoria et al. 2008). Complete resection of the primary tumour (resection status R0) is predictably associated with a better prognosis and patients in whom there is microscopic or macroscopic involvement of the tumour margins, 5-year survival is as low as 20 and 10\% respectively (Bilimoria et al. 2008). However, even in patients with R0 resection, recurrence and disease progression is still commonly seen, so that adjuvant therapy is frequently recommended.

The mainstay of adjuvant treatment is with the drug mitotane, a derivate from the insecticide dichlorodiphenyltrichloroethane. The adrenolytic nature of this drug has been well known since 1950s but its method of action has been poorly understood. Recently, the exact molecular target of mitotane has been identified as the enzyme sterol-o-Acyl transferase 1 (SOAT1/ACAT). SOAT1 is inhibited by mitotane, causing accumulation of fatty acids, oxysterols and free cholesterol (and concomitant reduction of cholesterol esters) in cells with high steroidogenic activity, leading to cell death via the endoplasmic stress response (Sbiera et al. 2015). SOAT1 is a mitochondria-associated membranes (MAM) protein and further evidence has shown that the disruption on MAM proteins may be important in the action of mitotane (Hescot et al. 2017).

Retrospective studies have shown that mitotane treatment improves recurrence-free survival in those with radically resected ACC compared to matched controls who underwent surgery alone (Terzolo et al. 2007, Else et al. 2014, Berruti et al. 2017). Data regarding overall survival are not clear-cut but trend towards mitotane shows benefit. The ADIUVO trial is a prospective randomised controlled trial looking at the effect of mitotane in patients with low/ intermediate risk of recurrence and is currently ongoing (ClinicalTrials.gov Identifier: NCT00777244). 
Currently, the only other adjuvant treatment shown to have effect is radiotherapy which two out of three studies have shown to improve rates of local recurrence however overall survival was not improved (Fassnacht et al. 2006, Sabolch et al. 2011, Habra et al. 2013).

Mitotane is currently the only medication approved by the U.S. Food and Drug Administration and European Medicine Executive Agency in advanced ACC. Systemic chemotherapy in the form of EDP-M (etoposide, doxorubicin, cisplatin and mitotane) has been shown in a randomised control trial to improve progressionfree survival and objective response rate; however, no significant overall survival benefit is reported when compared to treatment with mitotane and streptozotocin (14.8 and 12 months respectively) (Fassnacht et al. 2012).

Through better classification of disease in the form of scoring and staging as detailed above, management of ACC has improved over the last 40 years; however, the fact remains that for most, it is a life-limiting diagnosis. Although there have been no dramatic improvements in the management of this condition in clinical practice off late, the molecular understanding of adrenal self-renewal and adrenocortical tumourigenesis has improved exponentially. The advancement of genetic analysis in the form of next-generation sequencing and aided by bioinformatics has helped in the molecular characterisation of these tumours and opened up new avenues for investigation to improve understanding and ultimately clinical outcomes for patients with this condition.

\section{Self-renewal and signalling in the adrenal cortex}

As we have described earlier, ACC is a heterogeneous condition. The drug mitotane clearly has a role in the adjuvant setting, however, often fails to prevent progression especially in higher-risk disease. We now know that the molecular target of mitotane is the enzyme SOAT1, which is highly expressed in steroidogenic cells of the adrenal cortex (Sbiera et al. 2015). The same study also showed that SOAT1 expression was associated with a better response to mitotane treatment in terms of time to progression. However, despite the specific cytotoxicity of mitotane to steroidogenic cells of the adrenal cortex, progression frequently occurs. This has led to the theory that the presence of undifferentiated/poorly steroidogenic cells in the adrenal cortex, which are not affected by mitotane, may have a role in the development and chemoresistance of this malignancy.
Dysregulation of signalling pathways involved in the organogenesis and homeostasis of the adrenal cortex is implicated in many diseases, and it is theorised that corruption of these intricate processes are integral in the pathogenesis of ACC. Our understanding of the development and self-renewal of the adrenal cortex throughout life is informed mostly by rodent studies and by monogenic conditions affecting the development of the adrenal cortex. In addition, animal models of adrenal oncogenesis exist with heterogeneous penetrance of tumour formation (Basham et al. 2016, Leccia et al. 2016).

It has long been thought that the capsule and subcapsule are important sources of steroidogenic cells in the adrenal cortex and therefore a reservoir of stem/progenitor cells. This was first discovered in rats through the regeneration of the adrenal cortex from these layers after adrenal enucleation (Ingle \& Higgins 1938). Cell-labelling studies have indeed identified that adrenocortical cells progress centripetally throughout life from the capsule towards the medulla where they undergo apoptosis and/or senescence (Vinson 2003). Since then, further studies using transgenic animals have identified the capsule/subcapsule as the site of stem and progenitor cells in the adult rodent and have delineated some of the pathways involved in the maintenance of stem cell populations and also in the differentiation of functional adrenocortical cells (Walczak \& Hammer 2015).

\section{Sonic hedgehog signalling pathway}

Sonic hedgehog (Shh) is a glycoprotein molecule and secreted ligand whose signalling pathway is known to have a key role in organogenesis (Bambakidis \& Onwuzulike 2012). It has been shown to have important paracrine effects in the development and self-renewal of the adrenal cortex (Walczak \& Hammer 2015). Shh expression is seen in the subcapsular regions of mouse and rat adrenals starting from e12.5 and e13.5 respectively (King et al. 2009, Guasti et al. 2011). In rats, this occurs as part of the undifferentiated zone (ZU) whereas in mice this occurs in discrete clusters in the zona glomerulosa (ZG), similar to the pattern seen in human adrenals (Boulkroun et al. 2011). Cells expressing Shh appear to have steroidogenic potential as they co-express steroidogenic factor-1 (SF1), a master regulator of adrenocortical differentiation and function. However, they are not functional, differentiated cells as they do not express the enzymes required for synthesis of mineralocorticoid or glucocorticoid hormones (King et al. 2009, Huang et al. 2010). 
Lineage-tracing studies have shown that capsular cells expressing the transcription factor Gli1, of the zinc finger glioma-associated oncogene family, delaminate into the cortex under Shh signalling. These cells lose their responsiveness to Shh and become fully mature steroidogenic cells forming the distinct histological and functional layers of the ZG (secreting aldosterone and expressing CYP11B2/aldosterone synthase) and zona fasciculata (ZF, secreting glucocorticoids and expressing CYP11B1/11ßhydroxylase) (King et al. 2009). Capsular Gli1 cells are therefore a source of steroidogenic progenitor cells. Most Gli1 progenitor cells also express Wilms tumour suppressor (Wt1) and Gata4. Wt1 lineages can also generate mature steroidogenic cells (Bandiera et al. 2013).

In rats, capsular Gli1 expression is tightly regulated by the protein delta-like homologue 1 (Dlk1) (Guasti et al. 2013). Dlk1 is a cleavable single-pass transmembrane protein and a member of the Notch/Delta/Serrate family (Falix et al. 2012). It is maternally imprinted and is expressed in embryological development and in immature cells (Floridon et al. 2000). In neuronal cells, Dlk1 expression maintains an undifferentiated phenotype and promotes clonogenicity, findings suggestive of cancer stem cell-like functionality (Kim et al. 2009). In the rat adrenal cortex, Dlk1 is co-expressed with Shh cells in the ZU (Guasti et al. 2013). Its expression is markedly modulated by remodelling of the gland triggered by the activation/ inactivation of the renin-angiotensin-aldosterone axis, a process likely involving the recruitment/latency of stem/progenitor cells. Moreover, Dlk1 itself functionally interacts with Shh in activating capsular Gli1 expression in a $\beta 1$ integrin-dependent fashion (Guasti et al. 2013). Further study of Dlk1 in adrenal self-renewal and tumour development is ongoing.

\section{Wnt/ק-catenin signalling pathway}

Another important pathway in adrenal development, self-renewal and homeostasis is canonical Wnt/ $\beta$-catenin signalling. The pathway is characterised by Wnt ligand binding to the Frizzled cell-surface receptor leading to the stabilisation and translocation of $\beta$-catenin to the nucleus, where it activities transcriptional targets through interaction with TCF/LEF transcription factors. In the absence of Wnt ligand, $\beta$-catenin-mediated gene transcription is inhibited by a destruction complex, which includes amongst others, the scaffold protein Axin, glycogen synthase kinase $3 \beta$ (GSK3 $\beta$ ), casein kinase $1 \alpha(\mathrm{CK} 1 \alpha)$ and the tumour suppressor adenomatous polyposis coli (APC). The destruction complex binds to and phosphorylates cytoplasmic $\beta$-catenin leading to degradation (reviewed by Kahn 2014).

Wnt/ $\beta$-catenin signalling plays a critical role in embryonic adrenocortical development and maintenance as an adult. This has been demonstrated experimentally in mice through targeted disruption of Wnt/ $\beta$-catenin signalling in cells expressing SF1. This results in adrenal aplasia in embryos by e18.5 and causes a progressive adrenal wasting in adults histologically consistent with adrenal failure (Kim et al. 2008). It is proposed that this pathway is integral in maintaining adult adrenal stem cell reserve, a theory furthered by the finding that most Shh+ and ZG cells in mice are Wnt responsive as determined by TCF/LEF transcriptional activity (Walczak et al. 2014).

Canonical Wnt signalling also has a role in zonation and steroidogenesis. This appears to be most important in the development and maintenance of ZG. Wnt signalling has been shown to be almost entirely restricted to ZG. Experimental activation of $\beta$-catenin signalling leads to upregulation of CYP11B2 and AT1R, two determinants of ZG identity (Berthon et al. 2010, 2014). Signalling through the Wnt4 ligand appears to be particularly important in ZG development, with homozygous Wnt4 loss in mice leading to decreased aldosterone secretion at birth (Heikkila et al. 2002). Recently, it has been proposed that Wnt4 signalling acts as a local relay for the R-spondin ligand pathway in the development of the ZG (Vidal et al. 2016). R-spondin ligands Rspo3 and Rspo1 act upon the leucine-rich repeat containing $\mathrm{G}$ protein-coupled receptor 5 (LGR5) in the ZG of humans and mice causing amplification of Wnt signalling (Shaikh et al. 2015, Vidal et al. 2016). This amplification is partly due to sequestration of zinc and ring finger 3 (ZNRF3) and ring finger 43 (RNF43), which are negative feedback regulators of Wnt/ $\beta$-catenin signalling (Hao et al. 2012, Zebisch et al. 2013). Rspo3 is expressed in Gli1-expressing cells in mice from e14.5 onwards. Knock out of Rspo3 in mice causes Shh and Gli1 loss in the embryonic adrenal. It also causes loss of CYP11B2 and therefore aldosterone production. In adult mice, Rspo3 loss also causes loss of Shh expression and thinning of ZG (Vidal et al. 2016). It has been postulated that Rspo3 and Wnt canonical signalling therefore are important in maintaining the stem/progenitor cell population in the adrenal cortex, more so than Shh signalling alone as the degree of ZG differentiation loss and thinning is more profound in Rspo3 knock out compared to Shh knock out in mice (Huang et al. 2010, Vidal et al. 2016). 


\section{Fibroblast growth factors}

In addition to Shh and Wnt signalling, there is an established role for fibroblast growth factors (FGFs) in the development of many organs including the adrenal (Ornitz \& Itoh 2001, Guasti et al. 2013). In mice, knock out of the IIIb isoform of FGF receptor 2 (Fgfr2 IIIb) results in reduced cortical proliferation and adrenal hypoplasia. Cells expressing this receptor are found in the subcapsule of the mouse, in cells that express Shh. In Fgfr2 IIIb knock out models, there is an increase in Gli1+ cells in the capsule suggesting FGF may negatively regulate Shh signalling. Dlk1 signalling is also lost in this transgenic model, further suggesting a role for Dlk1 in maintaining an undifferentiated cell phenotype in the adrenal cortex (Guasti et al. 2013).

\section{Insulin-like growth factor $\mathbf{2}$ signalling}

Another important growth factor in adrenal development is the paternally expressed insulin-like growth factor 2 (IGF2). IGF2 is the only insulin-like growth factor ligand that is highly expressed in human foetal adrenal (Rainey et al. 2001). IGF2 binds to IGF1 receptor (IGF-1R) and the insulin receptor isoform A (INSR-A) to activate MAPK and PI3K-AKT signalling pathways. This causes promotion of cell growth and cell survival. IGF2 appears important in the embryological rodent adrenal as mice with loss of IGF signalling fail to develop adrenal cortices (reviewed by Dupont \& Holzenberger 2003). IGF2 expression in human adrenals decreases quickly after birth (Belgorosky et al. 2009) furthering the hypothesis that it plays a more important role in the embryological development of the adrenal and establishing the cellular architecture for the stem/progenitor pool rather than maintaining it.

\section{cAMP/PKA signalling pathway}

The subcapsule and ZG are the sites for the majority of the signalling pathways highlighted above, although cells of the ZF also originate from Gli1+ and Shh+ lineage (King et al. 2009). As we know, the functional layers of the adrenal cortex are populated developmentally and as part of a self-renewal process throughout life centripetally from stem/progenitor cells in the subcapsule (King et al. 2009, Freedman et al. 2013). Lineage-tracing experiments have shown that this likely occurs through initial differentiation into ZG phenotype and then subsequent lineage conversion to ZF cells (Freedman et al. 2013). A direct conversion of cortical Shh+ cells to ZF cells could also be possible. The cyclic adenosine monophosphate (cAMP)/protein kinase A (PKA) signalling pathway is essential for the development and maintenance of functional ZF. Binding of adrenocorticotropic hormone (ACTH) to the melanocortin 2 receptor (MC2R) activates the cAMP/PKA pathway resulting in progression of cells into ZF phenotype (Chida et al. 2007, Gorrigan et al. 2011). Recently, it has been shown that activation of this pathway inhibits canonical Wnt signalling. This leads to decrease in Wnt4-mediated ZG differentiation and facilitates lineage conversion to $\mathrm{ZF}$, suggesting an intricate interplay between cAMP/PKA and Wnt/ $\beta$-catenin signalling in the development and maintenance of the functional adrenocortical zones (Drelon et al. 2016a).

It is plausible to speculate that physiologically normal cell populations involved in self-renewing developmental pathways (thus regulating stem to progenitor to partially differentiated steroidogenic cells) might be corrupted by oncogenic processes leading to a clinically manifesting ACC. The current understanding of zonation and factors affecting self-renewal as detailed above has been schematised in Fig. 1.

\section{Genetic alterations in ACC}

Developments in high-throughput genomic assays have led to a detailed molecular characterisation of adrenocortical tumours. Integration of these results with the current understanding of physiological adrenal cortical development and homeostasis has improved understanding of the molecular pathogenesis of ACC.

\section{Insulin-like growth factor $\mathbf{2}$ signalling}

An important study looking at the gene expression profile of ACC compared with other benign adrenal pathology was published in 2003. Using Affymetrix microarrays, Giordano and colleagues compared the gene expression of 11 ACC, four adrenocortical adenomas (ACA), three normal adrenal cortices and one macronodular hyperplastic adrenal. This study identified 91 genes with significantly increased expression in ACC compared to the other samples. This included clusters of genes associated with cell proliferation, notably IGF2 which was increased in 10/11 ACC. Few transcriptional changes were noted between normal adrenal cortices and the benign cortical processes and none they deemed statistically significant (Giordano et al. 2003).

IGF2 mRNA had previously been recognised as being significantly upregulated in ACC compared to other 


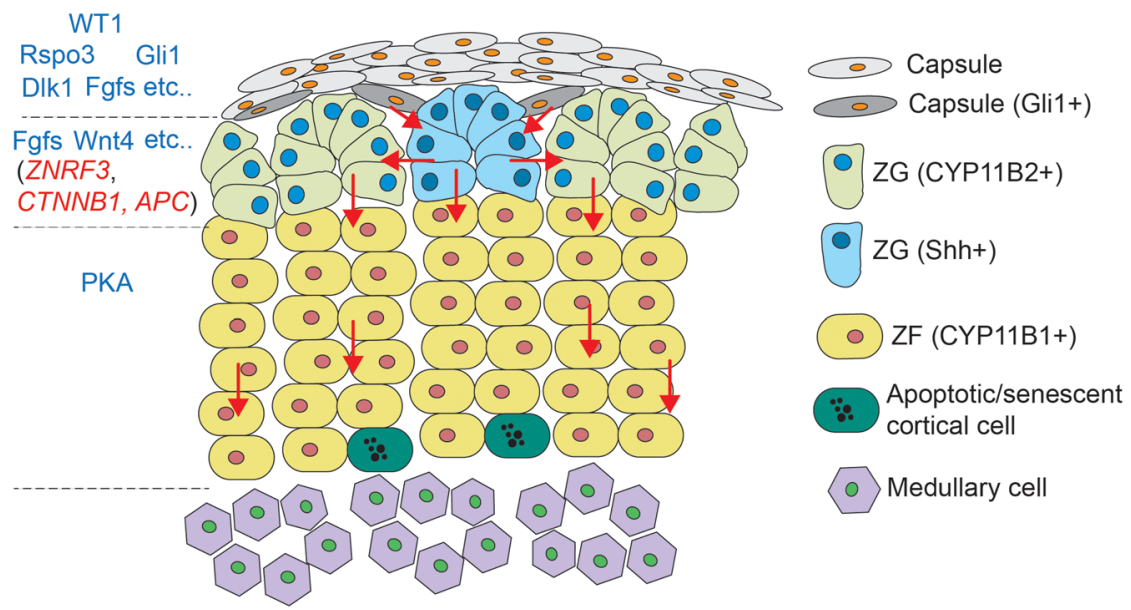

\section{Figure 1}

Schematic representation of the pathways involved in mouse adrenocortical self-renewal and zonation. Capsular Gli1 cells respond to Shh signalling, secreted by discreet clusters of subcapsular cortical cells, by delaminating and migrating into the cortex. The activation of canonical Wnt signalling is concentrated in the ZG and is dependent on the secretion of Rspo3 by Gli1 cells (Shh positive) in the rat. Zonal specific secreted factors/morphogens/ transcription factors/pathways, which have been implicated in adrenocortical self-renewal, are indicated in blue on the left. Newly generated ZG steroidogenic cells can transdifferentiate into ZF cells under CAMP/PKA signalling (although a Shh to ZF conversion is also possible). Steroidogenic cells are characterised by centripetal migration and undergo apoptosis/senescence at the cortical/medullary boundary. Genes known to be mutated in ACC and part of the Wnt/ $\beta$-catenin pathway are identified in red. The nature of cells co-opted by other known oncogenic mutations (TP53, CDKN2A, MEN1 etc.) is unknown.

adrenocortical pathology (Ilvesmäki et al. 1993, Gicquel et al. 1994). Increased IGF2 expression is also implicated in one of the familial genetic conditions that predispose patients to ACC, Beckwith-Wiedemann syndrome. This syndrome is associated with overgrowth, anterior abdominal wall defects and macroglossia. In $10 \%$ of cases, there is an increased risk of tumour development, predominantly Wilms tumours, rhabdomyosarcomas, hepatoblastomas and adrenocortical tumours. In this condition, there is altered expression of imprinted genes in the region 11p15.4-p15.5, including IGF2 (Li et al. 1997).

IGF2 expression is increased in up to $85 \%$ of adult ACC (Heaton et al. 2012, Zheng et al. 2016). In most cases, this is due to loss of heterozygosity at $11 \mathrm{p} 15$ locus, leading to loss of maternal imprinting and increased expression (Boulle et al. 1998, Gicquel et al. 2001). IGF2 does not appear to be a driver of ACC; however, it has been shown to have a role in disease prognostication. Early studies showed that overexpression of IGF2 was associated with a shorter disease-free survival (Gicquel et al. 2001). A further study using cDNA microarray analysis of 230 candidate genes in 33 ACA and 24 ACC identified a cluster of IGF2associated genes whose increased expression was a good predictor of malignancy in adrenocortical tumours. They also identified a cluster of genes related to steroidogenesis whose increased expression was associated with a lower risk of malignancy (de Fraipont et al. 2005). In paediatric ACC, IGF2 is increased in both ACA and ACC and does not have the same value in predicting malignancy (West et al. 2007).

\section{Prognostic clustering in ACC}

The molecular profile of ACC was further defined through two large studies looking at whole genome expression in ACC and ACA (de Reyniès et al. 2009, Giordano et al. 2009). A group from France and a group from USA both identified that in addition to being able to differentiate ACC from ACA, ACC in turn could be clustered into two different prognostic groups depending on transcriptome expression. In the high-risk cluster $(\mathrm{C} 1 \mathrm{~A})$, there was increased enrichment of genes involved with transcription, mitotic cell cycle and functional aneuploidy. The low-risk cluster (C1B) had enrichment of genes pertaining to cell differentiation, cell metabolism and apoptosis (de Reyniès et al. 2009, Giordano et al. 2009). These studies also both highlighted the heterogeneity of ACC compared to ACA as the variability was much higher in ACC than in ACA or normal cortex. The French study went on to highlight that the two clusters of ACCs can be more simply identified by combined expression of PINK1 (PTEN induced putative kinase 1) with $D L G 7$ (discs, large homologue 7) or BUB1B (budding uninhibited by benzimidazoles 1 homologue 
beta). Combined expression of PINK1 and DLG7 is the best predictor of disease-free survival and combined expression of PINK1 and $B U B 1 B$ is the best predictor of overall survival (de Reyniès et al. 2009). PINK1 and BUB1B combined expression has been independently validated as the best predictor of disease-free survival in a paediatric ACC cohort from Brazil (Fragoso et al. 2012).

\section{Wnt/ $\beta$-catenin signalling pathway}

The identification of molecularly annotated clusters of ACC has been validated and refined further by three independent, international studies performing pangenomic analyses of 122, 41 and 91 patients with ACC respectively (Assié et al. 2014a, Juhlin et al. 2015, Zheng et al. 2016). These studies have enabled the identification of driver genes in ACC (Table 1). In all of these studies, the most commonly altered gene is ZNRF3 (in 12-21\% of cases). As detailed above, ZNRF3 is a negative feedback regulator of Wnt signalling and its inactivation by mutations or homologous deletion leads to activation of canonical Wnt signalling. The same effect is also a result of activating mutations in CTNNB1, encoding $\beta$-catenin (in $9.8-16 \%$ of cases). These mutations are mutually exclusive in all three studies suggesting their function is through a common pathway in Wnt signalling (Assié et al. 2014a, Juhlin et al. 2015, Zheng et al. 2016). Mutations in APC, encoding part of the $\beta$-catenin destruction complex, were also recognised leading to increased activation of Wnt/ $\beta$ catenin signalling. Germline inactivating mutations in this gene are responsible for familial adenomatous polyposis 1 and its variant Gardner's syndrome. This condition, characterised by the development of numerous colorectal adenomatous polyps and cancer, is associated with a higher incidence of developing ACC (Barlaskar \& Hammer 2007, Kerr et al. 2013).

\section{p53 apoptosis/Rb1 cell cycle pathway}

Across these studies, Wnt signalling was the most commonly affected pathway (in 39-66\% of cases). The next most commonly affected pathway was that involving the p53 apoptosis/Rb1 cell cycle (in 19.5-44.9\% of cases). TP53 inactivating mutations are implicated in more than $50 \%$ of human cancers (Leroy et al. 2014). TP53 encodes the transcription factor p53, which has a crucial tumour suppressor role in cells. DNA damage and cellular stress signals result in p53 activation leading to DNA repair or apoptosis/senescence where damage is irreparable. p53 activation occurs under the influence of a pathway starting with the tumour suppressor gene CDKN2A. This gene encodes two proteins, p16 $6^{\mathrm{INK} 4 \mathrm{a}}$ and $\mathrm{p} 14^{\mathrm{ARF}}$. p14 $4^{\mathrm{ARF}}$ production in response to cell damage causes disinhibition of p53 production through inhibition of MDM2, which is responsible for p53 degradation. p16 ${ }^{\text {INK4a }}$ also plays a tumour suppressor role by causing increased expression of E2F-dependent genes, blocking G1/S cell cycle progression. This occurs through inhibition of the inactivation of $\mathrm{pRb}$ by phosphorylation under the influence of CDK4. E2Fdependent gene expression also leads to increased p14 ${ }^{\mathrm{ARF}}$ production and in turn p53 production (reviewed in Pacifico \& Leone 2007).

Similar to other malignancies, inactivation of p53 activity has long been recognised in ACC. Somatic TP53 mutations have previously been reported in approximately 30\% of sporadic ACCs (Reincke et al. 1994, Sidhu et al. 2005, Libe et al. 2007). In addition, loss of heterozygosity at the TP53 locus, $17 \mathrm{p} 13$, is reported in as many as $80 \%$ of cases (Libe et al. 2007). Further analysis of the original ACC clusters C1A and C1B identified by de Reyniès in 2009 revealed that TP53-mutated tumours were associated with the more aggressive phenotype (de Reyniès et al. 2009, Ragazzon et al. 2010). The same study also showed that activating $\beta$-catenin mutations were also associated

Table 1 Most common genetic alterations in adrenocortical carcinoma.

\begin{tabular}{|c|c|c|c|c|}
\hline Pathway affected & Gene & $\begin{array}{c}\text { Frequency alteration in } \\
\text { series (122 cases) } \\
\text { (Assié et al. } 2014 a)(\%)\end{array}$ & $\begin{array}{c}\text { Frequency alteration in } \\
\text { series (41 cases) } \\
\text { (Juhlin et al. 2015) (\%) }\end{array}$ & $\begin{array}{c}\text { Frequency alteration in } \\
\text { series (91 cases) } \\
\text { (Zheng et al. 2016) (\%) }\end{array}$ \\
\hline \multirow[t]{2}{*}{ Wnt/ $\beta$-catenin signalling } & ZNRF3 & 21 & 12 & 19 \\
\hline & CTNNB1 & 16 & 10 & 16 \\
\hline \multirow[t]{2}{*}{ p53 apoptosis/Rb1 cell cycle } & TP53 & 16 & 20 & 21 \\
\hline & CDKN2A & 11 & - & 15 \\
\hline \multirow[t]{2}{*}{ Chromatin remodelling/maintenance } & TERT & 6 & 22 & 14 \\
\hline & MEN1 & 7 & - & 7 \\
\hline cAMP/PKA signalling & PRKAR1A & - & - & 11 \\
\hline
\end{tabular}

Table detailing the most commonly altered genes in adrenocortical carcinoma identified by the three pan-genomic analyses. A cut-off of $7 \%$ in two or more studies was used. When not stated, the frequency was not published in that study. 
with the more aggressive phenotype and were mutually exclusive from TP53 mutations in this cohort (Ragazzon et al. 2010). This finding, however, was not repeated in two of the pan-genomic studies, which showed that TP53 and CTNNB1 mutations can co-exist in ACC (Assié et al. 2014a, Zheng et al. 2016).

Germline TP53 mutations are found in $50-75 \%$ of children with ACC (Pinto et al. 2015, Wasserman et al. 2015). These often occur in the context of Li-Fraumeni or Li-Fraumeni-like syndromes. Li-Fraumeni is a syndrome diagnosed clinically, associated with early-onset bone and soft tissue sarcomas and other early onset malignancies, including ACC in $10 \%$ of patients (Li \& Fraumeni 1969, Birch et al. 2001, Olivier et al. 2003). A specific TP53 mutation, c.1010G $>$ A (p.R337H), has been identified as being highly prevalent in southern Brazil where childhood incidence of ACC is increased by a factor of 10-15 (Achatz et al. 2007). This mutation, where arginine is replaced by histidine at codon 337 in exon 10, results in failure of oligodimerisation between two p53 monomers leading to decreased transactivation of downstream target genes (DiGiammarino et al. 2002).

The three large pan-genomic studies recently have further demonstrated the involvement of TP53 mutations in ACC (in 16-21.5\% of cases) (Assié et al. 2014a, Juhlin et al. 2015, Zheng et al. 2016). In addition, they have identified other alterations in parts of the tumour suppressor and cell cycle regulation pathway, notably inactivation of CDKN2A (11-15\% of cases) (Assié et al. 2014a, Zheng et al. 2016). Inactivation of RB1 and highlevel amplification of CDK4 and MDM2 were also noted in both studies leading to a functional loss of tumour suppression ability (Assié et al. 2014a, Zheng et al. 2016). CCNE1 activation, leading to decreased $\mathrm{Rb}$ action, has also been identified as a driver mutation affecting this pathway (Zheng et al. 2016).

\section{Chromatin remodelling/maintenance}

Another consistent finding across two of these studies was mutations in genes associated with chromatin remodelling, including DAXX, ATRX and more prominently MEN1 (in 7\% of cases) (Assié et al. 2014a, Zheng et al. 2016). MEN1 encodes the tumour suppressor, menin, which is a tissue-specific protein and has been reported to interact with histone methyltransferases (e.g. MLL, MLL2) and with transcriptional factors, including notably $\beta$-catenin, which has been shown to directly interact with and downregulate through degradation in vitro (Wu \& Hua 2008, Kim et al. 2017). Mutations in the genes encoding histone modification $M L L, M L L 2$ and MLL4 were identified in the most recent pan-genomic analysis, which described a cumulative incidence of driver mutations in histone modification and chromatin remodelling genes (excluding MEN1 - which they included as part of Wnt signalling) in $22 \%$ of cases - suggestive of a role of epigenetic dysregulation in the pathogenesis of ACC (Zheng et al. 2016).

In addition, the histone methyltransferase EZH2 has been shown to be upregulated both in histological samples and in gene expression data from three cohorts (Ip et al. 2015, Drelon et al. 2016b). EZH2 functions as a transcriptional repressor causing nucleosomal H3 methylation resulting in chromatin condensation and gene silencing (Cao et al. 2012). Increased EZH2 expression is a result of deregulated $\mathrm{P} 53 / \mathrm{RB} / \mathrm{E} 2 \mathrm{~F}$ pathway activity and is associated with more aggressive disease phenotype and worse prognosis (Drelon et al. 2016b).

Genes affecting chromatin maintenance have also been identified as drivers in ACC. TERT encodes telomerase reverse transcriptase, an enzymatic protease that prevents the telomerase shortening associated with normal cell division and replication associated with ageing and senescence (Greider \& Blackburn 1987). High-level amplifications of this gene were noted across the studies (in 7-14\% of cases) (Assié et al. 2014a, Juhlin et al. 2015, Zheng et al. 2016). Telomeric repeat-binding factor 2, TERF2, has also been identified as being focally amplified in 7\% of cases (Zheng et al. 2016).

\section{CAMP/PKA signalling pathway}

In the most recent pan-genomic cohort, $8 \%$ of cases had inactivating mutations in the protein kinase cAMPdependent regulatory type I alpha gene (PRKAR1A) (Zheng et al. 2016). Germline-inactivating mutations in this gene are associated with benign primary pigmented nodular adrenocortical disease and Carney Complex (Kirschner et al. 2000). This is an autosomal dominant condition characterised by endocrine neoplasia, such as adrenocortical adenoma, increased spotted skin pigmentation, cardiac myxomas and schwannomas (Carney et al. 1985). These conditions are usually associated with benign adrenal disease; however, malignant transformation has been reported (Anselmo et al. 2012). Further to this, an activating mutation in the catalytic subunit of the cAMP-dependent protein kinase A (PKA) (PRKACA) has been discovered in cortisol-producing adenomas (Beuschlein et al. 2014). Together this evidence is suggestive of a role of alteration in cAMP/PKA signalling 
in the formation of adrenocortical tumours and in the development of ACC.

\section{Methylome analysis}

In addition to driver gene identification, two of these studies have also provided an in-depth analysis of the DNA methylation, miRNA analysis and chromosomal alterations in ACC (Assié et al. 2014a, Zheng et al. 2016). This information has validated previous work and helped further in defining prognostic groups. CpG islands are sequences of DNA rich in CG bases and are located in the promoter sequence of genes. Methylation status of these islands regulates gene expression. Global hypomethylation results in genomic instability and is observed in cancer (Kulis \& Esteller 2010). However, hypermethylation of CpG islands in genomic areas encoding tumour suppressor genes is also recognised in malignancy (Kalari \& Pfeifer 2010). In ACC, it has been reported that intergenic regions are hypomethylated compared to ACA (Rechache et al. 2012). In addition, there are over 200 hypermethylated promoter regions compared to ACA, including known tumour suppressor genes (Fonseca et al. 2012). The pangenomic analyses showed that $\mathrm{CpG}$ island methylated phenotype (CIMP) was also associated with the previously identified disease clusters in ACC, C1A and C1B (Assié et al. 2014a, Zheng et al. 2016). High CIMP, referring to hypermethylated profiles, were found to be exclusively in the more aggressive ACC cluster C1A, with lower levels of methylation showing a better prognostic value even within this cluster (Assié et al. 2014a). Zheng and colleagues have taken this further to classify new clusters of clusters (CoC I-III) based on CIMP. Tumours with low CIMP fall into CoC I and are almost analogous with the previous cluster $\mathrm{C} 1 \mathrm{~B}$. The old $\mathrm{C} 1 \mathrm{~A}$ has been further split into CoC II with intermediate CIMP and CoC III with high CIMP, which carries the worst prognosis (Zheng et al. 2016). Since this study another group has shown that DNA hypermethylation, measured using methylationspecific multiplex ligation-dependent probe amplification (MS-MLPA) is an independent marker of prognostication in ACC for overall and disease-free survival (Jouinot et al. 2016)

\section{miRNAome analysis}

The microRNA (miRNA) expression profile of tumours can also be used to differentiate ACC from ACA. MicroRNAs are small non-coding RNAs that act to regulate posttranscriptional gene expression. Interpreting the functional significance of individual miRNA profiles can be difficult as each miRNA may act upon more than one mRNA transcript. The first large study looking into miRNA in adrenal cancer identified that ACC had significantly lower levels of expression of miR-195 and miR-335 than ACA (Soon et al. 2009). miR-7 is also significantly raised in normal tissue compared to ACC and ACA and is significantly more reduced in ACA vs ACC. This study also identified that low levels of miR-195 and higher levels of miR-483-5p were predictive of a more aggressive disease course within in ACC (Soon et al. 2009). miR-483 is located in intron 2 of the IGF2 locus and has subsequently been shown to be the most recurrent marker of malignancy in both tumour samples (Patterson et al. 2011) and as circulating miRNA in serum (Chabre et al. 2013). The European-based pan-genomic study reaffirmed this finding when comparing their original ACC cohort with three normal adrenal samples (Assié et al. 2014a). Using consensus clustering, they identified three stable miRNA tumour clusters (Mi1-3). Mi3 was predictive of C1A and Mi1 predictive of C1B. Zheng and colleagues generated six different miRNA clusters, which did not appear to show associations with the CoC classification (Zheng et al. 2016).

\section{Chromosomal alterations analysis}

Another apparent marker of ACC compared to ACA is the quantitative chromosomal alterations that are present (Assié et al. 2014b). The pan-genomic studies all highlighted common profiles of copy number alterations (CNAs) (Assié et al. 2014a, Juhlin et al. 2015, Zheng et al. 2016). Two of the studies have concordant analyses from their cohorts that a noisy pattern of CNA (compared to quiet or chromosomal) was associated with a shorter event-free survival (Assié et al. 2014a, Zheng et al. 2016). Whole genome doubling was frequently associated with loss of heterozygosity in tumours and was also associated with a more aggressive phenotype (Zheng et al. 2016). A recent study has highlighted the potential diagnostic and prognostic benefit of assessing chromosomal alterations by correlating mutations and copy number variations to ACC histotype. A lower mutation burden was identified in oncocytic tumours and the highest in the conventional and myxoid ACCs (Vatrano et al. 2018).

\section{Conclusion}

In this review, we have detailed the pathobiology and genetic alterations in adrenocortical carcinoma through 
integrating current understanding of homeostasis and self-renewal in the normal adrenal cortex with molecular profiling of tumours from recent genetic analyses. Pathways involved in self-renewal and development of the gland, namely Wnt/ $\beta$-catenin and cAMP/PKA, are recognised to be altered in large cohorts of ACC tumour samples. Activation of $\mathrm{Wnt} / \beta$-catenin signalling is present in $39-66 \%$ of cases studied and this would seem to play an important role in the overall pathogenesis of ACC (Assié et al. 2014a, Juhlin et al. 2015, Zheng et al. 2016). Given that Wnt/ $\beta$-catenin signalling has recently been shown to be inhibited by cAMP/PKA pathway activation, an event shown to occur in ACC though PRKAR1A-inactivating mutations, the contribution of Wnt/ $\beta$-catenin dysregulation in ACC may be even higher (Drelon et al. 2016a). It is striking that all three of the pangenomic analyses have identified activating CTNNB1 and inactivating mutations in ZNRF3 to be mutually exclusive events adding further weight to the role of the net effect of canonical Wnt signalling activation in this disease (Assié et al. 2014a, Juhlin et al. 2015, Zheng et al. 2016).

Activation of IGF2 signalling is the most frequently recognised molecular annotation in ACC, occurring in up to $85 \%$ of cases studied and proving, in adults, to be a good predictor of malignancy when comparing ACA and ACC (de Fraipont et al. 2005, Heaton et al. 2012, Zheng et al. 2016). It has proven difficult to pinpoint clearly a pathogenetic role for increased IGF2 expression in ACC as mice models have shown that overexpression of IGF2 alone can cause adrenal hyperplasia but not neoplastic transformation (Weber et al. 1999, Drelon et al. 2012). However, in the presence of constitutively active Wnt $/ \beta$ catenin signalling in these models, increased IGF2 expression does lead to the formation of a small number of ACCs. These studies are suggestive that more is at play, either in the form of other somatic mutations or epigenetic alterations (Drelon et al. 2012, Heaton et al. 2012). In addition, initial clinical trials using compounds that inhibit IGF2 signalling have failed to show significant tumour regression in adequate number of patients (Haluska et al. 2010, Lerario et al. 2014). A further trial with an oral IGF-1R inhibitor, linsitinib, showed no improvement in overall or disease-free survival in locally advanced and metastatic disease compared with placebo (Fassnacht et al. 2015).

IGF2 signalling in the adrenal has characteristics of a process involved in embryonic organ development rather than in gland self-renewal. These are namely, its paternal expression and its decrease in expression shortly after birth in normal human adrenals (Rainey et al. 2001). It is possible that in addition to its putative cumulative effect in tumourigenesis, IGF2 expression signifies a more global molecular reversion to a developmental, stem/progenitor phenotype and that other as yet undefined paternally expressed genes encoding similar pathways may have a more active role in cancer formation.

Other pathways identified to be altered in ACC include p53 apoptosis/Rb1 cell cycle and alteration in chromatin modelling and maintenance. These changes are recognised in other malignancies also, and it is not yet clear how corruption of these pathways fit into the pathogenesis of ACC. The fact that two cohorts of molecularly profiled ACC showed activating $\beta$-catenin mutations and inactivating p53 mutations to be mutually exclusive events (Ragazzon et al. 2010, Juhlin et al. 2015) is suggestive that these may be separate pathways in the formation of this malignancy; however, larger studies have shown small numbers of cases with alterations in both (Assié et al. 2014a, Zheng et al. 2016). This is indicative of the heterogeneity of this condition, where recurrent driver mutations are not shared in $40 \%$ of cases (Assié et al. 2014a).

It is clear that ACC is a widely diverse condition in phenotype, molecular profile and pathogenesis. Recognition of the molecular alterations in these tumours along with better understanding of the pathways of physiological homeostasis in the normal adrenal cortex have improved our understanding of this condition enormously. The recent pan-genomic analyses have shown clear correlations between molecular profiles and prognosis and have intricately expanded the clustering of disease (Assié et al. 2014a, Zheng et al. 2016). However, we are yet to see the use of this wealth of molecular information affect therapeutic strategies in the clinical setting.

The knowledge of tumour molecular profiling has also aided in progression in a new area of diagnostics in cancer, the liquid biopsy. This refers to tumour-related material that is detectable in the bloodstream and includes circulating tumour cells, miRNA, circulating tumour DNA and exosomes. It offers the potential of molecular classification and thereby hopefully prognostication of adrenocortical tumours prior to surgery with a simple blood test. Recently, a study has shown that circulating tumour DNA can be detected in a subset of patients with ACC and that the DNA seemed to follow tumour dynamics including mutations in known driver genes in ACC (Garinet et al. 2018). However, in some patients, no circulating tumour DNA was detectable even in those with a large tumour burden, highlighting the challenges 
in the development of this technique. Plasma analysis for microRNAs has shown that miR-483-5p, whose upregulation is recognised in tumours, is also upregulated in serum and plasma in ACC and levels were predictive of more advanced disease stages (Chabre et al. 2013, Salvianti et al. 2017). Both plasma ctDNA and miRNA have limitations in the amount of information derivable from prognostication purposes. This is not a problem for circulating tumour cells, which have the advantage of the possibility of genetic molecular profiling. These are starting to be used to profile other more common malignancies, and a proof-of-concept study has shown they are detectable in ACC compared with ACA (Pinzani et al. 2013); however, larger international collaborations with thorough molecular profiling are required to assess their actual prognostic value in ACC. Development of these techniques will provide a thorough molecular characterisation of ACC at the point of diagnosis.

It seems likely that the next tangible clinical effector in management of adrenocortical carcinoma will come in the form of improved disease staging and prognostication, initially histologically through advances in immunohistochemistry but also through molecular characterisation of disease post-operatively and eventually pre-operatively through liquid biopsy.

A better understanding of the mechanisms underlying self-renewal and stem cell hierarchy in human normal adrenal cortices, together with the identification of cell populations likely to be co-opted by oncogenic mutations, will facilitate further elucidation and definition of the molecular pathways involved in the pathogenesis of ACC. The combination of these advances will lead to the development of novel effective and personalised strategies to eradicate molecularly annotated ACCs.

\section{Declaration of interest}

The authors declare that there is no conflict of interest that could be perceived as prejudicing the impartiality of this review.

\section{Funding}

The support of Rosetrees Trust and Barts Charity is greatly acknowledged. J P is supported by a Joan Adams Research Fellowship and a Barts and The London Charity Academic Clinical Fellowship.

\section{References}

Achatz MIW, Olivier M, Le Calvez F, Martel-Planche G, Lopes A, Rossi BM, Ashton-Prolla P, Giugliani R, Palmero EI, Vargas FR, et al. 2007 The TP53 mutation, R337H, is associated with Li-Fraumeni and
Li-Fraumeni-like syndromes in Brazilian families. Cancer Letters $\mathbf{2 4 5}$ 96-102. (https://doi.org/10.1016/J.CANLET.2005.12.039)

Anselmo J, Medeiros S, Carneiro V, Greene E, Levy I, Nesterova M, Lyssikatos C, Horvath A, Carney JA \& Stratakis CA 2012 A large family with carney complex caused by the S147G PRKAR1A mutation shows a unique spectrum of disease including adrenocortical cancer. Journal of Clinical Endocrinology and Metabolism 97 351-359. (https://doi.org/10.1210/jc.2011-2244)

Assié G, Letouzé E, Fassnacht M, Jouinot A, Luscap W, Barreau O, Omeiri H, Rodriguez S, Perlemoine K, René-Corail F, et al. 2014a Integrated genomic characterization of adrenocortical carcinoma. Nature Genetics 46 607-612. (https://doi.org/10.1038/ng.2953)

Assié G, Jouinot A \& Bertherat J 2014b The 'omics' of adrenocortical tumours for personalized medicine. Nature Reviews Endocrinology 10 215-228. (https://doi.org/10.1038/nrendo.2013.272)

Aubert S, Wacrenier A, Leroy X, Devos P, Carnaille B, Proye C, Wemeau JL, Lecomte-Houcke M \& Leteurtre E 2002 Weiss system revisited. American Journal of Surgical Pathology 26 1612-1619. (https://doi.org/10.1097/00000478-200212000-00009)

Bambakidis NC \& Onwuzulike K 2012 Sonic Hedgehog signaling and potential therapeutic indications. Vitamins and Hormones $\mathbf{8 8}$ 379-394. (https://doi.org/10.1016/B978-0-12-394622-5.00017-1)

Bandiera R, Vidal VPI, Motamedi FJ, Clarkson M, Sahut-Barnola I, vonGise A, Pu WT, Hohenstein P, Martinez A \& Schedl A 2013 WT1 maintains adrenal-gonadal primordium identity and marks a population of AGP-like progenitors within the adrenal gland. Developmental Cell 27 5-18. (https://doi.org/10.1016/j. devcel.2013.09.003)

Barlaskar FM \& Hammer GD 2007 The molecular genetics of adrenocortical carcinoma. Reviews in Endocrine and Metabolic Disorders 8 343-348. (https://doi.org/10.1007/s11154-007-9057-x)

Basham KJ, Hung HA, Lerario AM \& Hammer GD 2016 Mouse models of adrenocortical tumors. Molecular and Cellular Endocrinology 421 82-97. (https://doi.org/10.1016/j.mce.2015.11.031)

Belgorosky A, Baquedano MS, Guercio G \& Rivarola MA 2009 Expression of the IGF and the aromatase/estrogen receptor systems in human adrenal tissues from early infancy to late puberty: implications for the development of adrenarche. Reviews in Endocrine and Metabolic Disorders 10 51-61. (https://doi.org/10.1007/s11154-008-9105-1)

Berruti A, Grisanti S, Pulzer A, Claps M, Daffara F, Loli P, Mannelli M, Boscaro M, Arvat E, Tiberio G, et al. 2017 Long-term outcomes of adjuvant mitotane therapy in patients with radically resected adrenocortical carcinoma. Journal of Clinical Endocrinology and Metabolism 102 1358-1365. (https://doi.org/10.1210/jc.2016-2894)

Berthon A, Sahut-Barnola I, Lambert-Langlais S, de Joussineau C, Damon-Soubeyrand C, Louiset E, Taketo MM, Tissier F, Bertherat J, Lefrançois-Martinez A-M, et al. 2010 Constitutive beta-catenin activation induces adrenal hyperplasia and promotes adrenal cancer development. Human Molecular Genetics 19 1561-1576. (https://doi. org/10.1093/hmg/ddq029)

Berthon A, Drelon C, Ragazzon B, Boulkroun S, Tissier F, Amar L, Samson-Couterie B, Zennaro MC, Plouin PF, Skah S, et al. 2014 WNT/B-catenin signalling is activated in aldosteroneproducing adenomas and controls aldosterone production. Human Molecular Genetics 23 889-905. (https://doi.org/10.1093/hmg/ddt484)

Beuschlein F, Fassnacht M, Assié G, Calebiro D, Stratakis CA, Osswald A, Ronchi CL, Wieland T, Sbiera S, Faucz FR, et al. 2014 Constitutive activation of PKA catalytic subunit in adrenal Cushing's syndrome. New England Journal of Medicine 370 1019-1028. (https://doi. org/10.1056/NEJMoa1310359)

Beuschlein F, Weigel J, Saeger W, Kroiss M, Wild V, Daffara F, Libé R, Ardito A, Al Ghuzlan A, Quinkler M, et al. 2015 Major prognostic role of Ki67 in localized adrenocortical carcinoma after complete resection. Journal of Clinical Endocrinology and Metabolism 100 841-849. (https://doi.org/10.1210/jc.2014-3182) 
Bilimoria KY, Shen WT, Elaraj D, Bentrem DJ, Winchester DJ, Kebebew E \& Sturgeon C 2008 Adrenocortical carcinoma in the United States: treatment utilization and prognostic factors. Cancer 113 3130-3136. (https://doi.org/10.1002/cncr.23886)

Birch JM, Alston RD, McNally RJQ, Evans DGR, Kelsey AM, Harris M, Eden OB \& Varley JM 2001 Relative frequency and morphology of cancers in carriers of germline TP53 mutations. Oncogene $\mathbf{2 0}$ 4621-4628. (https://doi.org/10.1038/sj.onc.1204621)

Boulkroun S, Samson-Couterie B, Golib-Dzib JF, Amar L, Plouin PF, Sibony M, Lefebvre $\mathrm{H}$, Louiset E, Jeunemaitre X, Meatchi T, et al. 2011 Aldosterone-producing adenoma formation in the adrenal cortex involves expression of stem/progenitor cell markers. Endocrinology 152 4753-4763. (https://doi.org/10.1210/en.2011-1205)

Boulle N, Logié A, Gicquel C, Perin L \& Le Bouc Y 1998 Increased levels of insulin-like growth factor II (IGF-II) and IGF-binding protein-2 are associated with malignancy in sporadic adrenocortical tumors. Journal of Clinical Endocrinology and Metabolism 83 1713-1720. (https://doi.org/10.1210/jcem.83.5.4816)

Cao W, Ribeiro R de O, Liu D, Saintigny P, Xia R, Xue Y, Lin R, Mao L \& Ren H 2012 EZH2 promotes malignant behaviors via cell cycle dysregulation and its mRNA level associates with prognosis of patient with non-small cell lung cancer. PLoS ONE 7 e52984. (https://doi.org/10.1371/journal.pone.0052984)

Carney JA, Gordon H, Carpenter PC, Shenoy BV \& Go VL 1985 The complex of myxomas, spotty pigmentation, and endocrine overactivity. Medicine 64 270-283. (https://doi. org/10.1097/00005792-198507000-00007)

Chabre O, Libé R, Assie G, Barreau O, Bertherat J, Bertagna X, Feige JJ \& Cherradi N 2013 Serum miR-483-5p and miR-195 are predictive of recurrence risk in adrenocortical cancer patients. Endocrine-Related Cancer 20 579-594. (https://doi.org/10.1530/ERC-13-0051)

Chida D, Nakagawa S, Nagai S, Sagara H, Katsumata H, Imaki T, Suzuki H, Mitani F, Ogishima T, Shimizu C, et al. 2007 Melanocortin 2 receptor is required for adrenal gland development, steroidogenesis, and neonatal gluconeogenesis. PNAS 104 18205-18210. (https://doi.org/10.1073/pnas.0706953104)

de Fraipont F, El Atifi M, Cherradi N, Le Moigne G, Defaye G, Houlgatte R, Bertherat J, Bertagna X, Plouin P-F, Baudin E, et al. 2005 Gene expression profiling of human adrenocortical tu Hescot mors using complementary deoxyribonucleic acid microarrays identifies several candidate genes as markers of malignancy. Journal of Clinical Endocrinology and Metabolism 90 1819-1829. (https://doi. org/10.1210/jc.2004-1075)

de Reyniès A, Assié G, Rickman DS, Tissier F, Groussin L, René-Corail F, Dousset B, Bertagna X, Clauser E \& Bertherat J 2009 Gene expression profiling reveals a new classification of adrenocortical tumors and identifies molecular predictors of malignancy and survival. Journal of Clinical Oncology 27 1108-1115. (https://doi.org/10.1200/ JCO.2008.18.5678)

DiGiammarino EL, Lee AS, Cadwell C, Zhang W, Bothner B, Ribeiro RC, Zambeti G \& Kriwacki RW 2002 A novel mechanism of tumorigenesis involving $\mathrm{pH}$-dependent destabilization of a mutant p53 tetramer. Nature Structural Biology 9 12-16. (https://doi. org/10.1038/nsb730)

Drelon C, Berthon A, Ragazzon B, Tissier F, Bandiera R, Sahut-Barnola I, de Joussineau C, Batisse-Lignier M, Lefrançois-Martinez AM, Bertherat J, et al. 2012 Analysis of the role of Igf2 in adrenal tumour development in transgenic mouse models. PLOS ONE 7 e44171. (https://doi.org/10.1371/journal.pone.0044171)

Drelon C, Berthon A, Sahut-Barnola I, Mathieu M, Dumontet T, Rodriguez S, Batisse-Lignier M, Tabbal H, Tauveron I, LefrançoisMartinez A-M, et al. 2016a PKA inhibits WNT signalling in adrenal cortex zonation and prevents malignant tumour development. Nature Communications 7 12751. (https://doi.org/10.1038/ ncomms12751)
Drelon C, Berthon A, Mathieu M, Ragazzon B, Kuick R, Tabbal H, Septier A, Rodriguez S, Batisse-Lignier M, Sahut-Barnola I, et al. $2016 b$ EZH2 is overexpressed in adrenocortical carcinoma and is associated with disease progression. Human Molecular Genetics 25 2789-2800. (https://doi.org/10.1093/hmg/ddw136)

Dupont J \& Holzenberger M 2003 Biology of insulin-like growth factors in development. Birth Defects Research Part C: Embryo Today: Reviews 69 257-271. (https://doi.org/10.1002/bdrc.10022)

Duregon E, Volante M, Giorcelli J, Terzolo M, Lalli E \& Papotti M 2013 Diagnostic and prognostic role of steroidogenic factor 1 in adrenocortical carcinoma: a validation study focusing on clinical and pathologic correlates. Human Pathology 44 822-828. (https://doi. org/10.1016/j.humpath.2012.07.025)

Duregon E, Cappellesso R, Maffeis V, Zaggia B, Ventura L, Berruti A, Terzolo M, Fassina A, Volante M \& Papotti M 2017 Validation of the prognostic role of the 'Helsinki Score' in 225 cases of adrenocortical carcinoma. Human Pathology 62 1-7. (https://doi.org/10.1016/J. HUMPATH.2016.09.035)

Else T, Kim AC, Sabolch A, Raymond VM, Kandathil A, Caoili EM, Jolly S, Miller BS, Giordano TJ \& Hammer GD 2014 Adrenocortical carcinoma. Endocrine Reviews 35 282-326. (https://doi.org/10.1210/ er.2013-1029)

Falix FA, Aronson DC, Lamers WH \& Gaemers IC 2012 Possible roles of DLK1 in the Notch pathway during development and disease. Biochimica et Biophysica Acta: Molecular Basis of Disease 1822 988-995. (https://doi.org/10.1016/j.bbadis.2012.02.003)

Fassnacht M \& Allolio B 2009 Clinical management of adrenocortical carcinoma. Best Practice and Research Clinical Endocrinology and Metabolism 23 273-289. (https://doi.org/10.1016/j.beem.2008.10.008)

Fassnacht M, Hahner S, Polat B, Koschker AC, Kenn W, Flentje M \& Allolio B 2006 Efficacy of adjuvant radiotherapy of the tumor bed on local recurrence of adrenocortical carcinoma. Journal of Clinical Endocrinology and Metabolism 91 4501-4504. (https://doi. org/10.1210/jc.2006-1007)

Fassnacht M, Johanssen S, Quinkler M, Bucsky P, Willenberg HS, Beuschlein F, Terzolo M, Mueller HH, Hahner S \& Allolio B 2009 Limited prognostic value of the 2004 international union against cancer staging classification for adrenocortical carcinoma. Cancer 115 243-250. (https://doi.org/10.1002/cncr.24030)

Fassnacht M, Terzolo M, Allolio B, Baudin E, Haak H, Berruti A, Welin S, Schade-Brittinger C, Lacroix A, Jarzab B, et al. 2012 Combination chemotherapy in advanced adrenocortical carcinoma. New England Journal of Medicine 366 2189-2197. (https://doi.org/10.1056/ NEJMoa1200966)

Fassnacht M, Berruti A, Baudin E, Demeure MJ, Gilbert J, Haak H, Kroiss M, Quinn DI, Hesseltine E, Ronchi CL, et al. 2015 Linsitinib (OSI-906) versus placebo for patients with locally advanced or metastatic adrenocortical carcinoma: a double-blind, randomised, phase 3 study. Lancet Oncology 16 426-435. (https://doi.org/10.1016/ S1470-2045(15)70081-1)

Floridon C, Jensen CH, Thorsen P, Nielsen O, Sunde L, Westergaard JG, Thomsen SG \& Teisner B 2000 Does Fetal antigen 1 (FA1) identify cells with regenerative, endocrine and neuroendocrine potentials? A study of FA1 in embryonic, fetal, and placental tissue and in maternal circulation. Differentiation 66 49-59. (https://doi. org/10.1046/J.1432-0436.2000.066001049.X)

Fonseca AL, Kugelberg J, Starker LF, Scholl U, Choi M, Hellman P, Åkerström G, Westin G, Lifton RP, Björklund P, et al. 2012 Comprehensive DNA methylation analysis of benign and malignant adrenocortical tumors. Genes, Chromosomes and Cancer 51 949-960. (https://doi.org/10.1002/gcc.21978)

Fragoso MC, Almeida MQ, Mazzuco TL, Mariani BMP, Brito LP, Goncalves TC, Alencar GA, Lima LO, Faria AM, Bourdeau I, et al. 2012 Combined expression of BUB1B, DLGAP5, and PINK1 as predictors of poor outcome in adrenocortical tumors: validation in a 
Brazilian cohort of adult and pediatric patients. European Journal of Endocrinology 166 61-67. (https://doi.org/10.1530/EJE-11-0806)

Freedman BD, Kempna PB, Carlone DL, Shah MS, Guagliardo NA, Barrett PQ, Gomez-Sanchez CE, Majzoub JA \& Breault DT 2013 Adrenocortical zonation results from lineage conversion of differentiated zona glomerulosa cells. Developmental Cell 26 666-673. (https://doi.org/10.1016/j.devcel.2013.07.016)

Garinet S, Nectoux J, Neou M, Pasmant E, Jouinot A, Sibony M, Orhant L, Da Fonseca JP, Perlemoine K, Bricaire L, et al. 2018 Detection and monitoring of circulating tumor DNA in adrenocortical carcinoma. Endocrine-Related Cancer 25 L13-L17. (https://doi.org/10.1530/ERC-17-0467)

Gicquel C, Bertagna X, Schneid H, Francillard-Leblond M, Luton JP, Girard F \& Le Bouc Y 1994 Rearrangements at the 11p15 locus and overexpression of insulin-like growth factor-II gene in sporadic adrenocortical tumors. Journal of Clinical Endocrinology and Metabolism 78 1444-1453. (https://doi.org/10.1210/ jcem.78.6.7911125)

Gicquel C, Bertagna X, Gaston V, Coste J, Louvel A, Baudin E, Bertherat J, Chapuis Y, Duclos JM, Schlumberger M, et al. 2001 Molecular markers and long-term recurrences in a large cohort of patients with sporadic adrenocortical tumors. Cancer Research $\mathbf{6 1}$ 6762-6767.

Giordano TJ, Thomas DG, Kuick R, Lizyness M, Misek DE, Smith AL, Sanders D, Aljundi RT, Gauger PG, Thompson NW, et al. 2003 Distinct transcriptional profiles of adrenocortical tumors uncovered by DNA microarray analysis. American Journal of Pathology 162 521-531. (https://doi.org/10.1016/S0002-9440(10)63846-1)

Giordano TJ, Kuick R, Else T, Gauger PG, Vinco M, Bauersfeld J, Sanders D, Thomas DG, Doherty G \& Hammer G 2009 Molecular classification and prognostication of adrenocortical tumors by transcriptome profiling. Clinical Cancer Research 15 668-676. (https:// doi.org/10.1158/1078-0432.CCR-08-1067)

Gorrigan RJ, Guasti L, King P, Clark AJ \& Chan LF 2011 Localisation of the melanocortin-2-receptor and its accessory proteins in the developing and adult adrenal gland. Journal of Molecular Endocrinology 46 227-232. (https://doi.org/10.1530/JME-11-0011)

Greider CW \& Blackburn EH 1987 The telomere terminal transferase of tetrahymena is a ribonucleoprotein enzyme with two kinds of primer specificity. Cell 51 887-898. (https://doi.org/10.1016/00928674(87)90576-9)

Guasti L, Paul A, Laufer E \& King P 2011 Localization of Sonic hedgehog secreting and receiving cells in the developing and adult rat adrenal cortex. Molecular and Cellular Endocrinology 336 117-122. (https:// doi.org/10.1016/j.mce.2010.11.010)

Guasti L, Candy Sze WC, McKay T, Grose R \& King PJ 2013 FGF signalling through Fgfr2 isoform IIIb regulates adrenal cortex development. Molecular and Cellular Endocrinology 371 182-188. (https://doi.org/10.1016/j.mce.2013.01.014)

Habra MA, Ejaz S, Feng L, Das P, Deniz F, Grubbs EG, Phan A, Waguespack SG, Ayala-Ramirez M, Jimenez C, et al. 2013 A retrospective cohort analysis of the efficacy of adjuvant radiotherapy after primary surgical resection in patients with adrenocortical carcinoma. Journal of Clinical Endocrinology and Metabolism 98 192-197. (https://doi.org/10.1210/jc.2012-2367)

Haluska P, Worden F, Olmos D, Yin D, Schteingart D, Batzel GN, Paccagnella ML, De Bono JS, Gualberto A \& Hammer GD 2010 Safety, tolerability, and pharmacokinetics of the anti-IGF-1R monoclonal antibody figitumumab in patients with refractory adrenocortical carcinoma. Cancer Chemotherapy and Pharmacology 65 765-773. (https://doi.org/10.1007/s00280-009-1083-9)

Hao HX, Xie Y, Zhang Y, Zhang O, Oster E, Avello M, Lei H, Mickanin C, Liu D, Ruffner H, et al. 2012 ZNRF3 promotes Wnt receptor turnover in an R-spondin-sensitive manner. Nature $\mathbf{4 8 5}$ 195-202. (https://doi.org/10.1038/nature11019)
Heaton JH, Wood MA, Kim AC, Lima LO, Barlaskar FM, Almeida MQ, Fragoso MCB V, Kuick R, Lerario AM, Simon DP, et al. 2012 Progression to adrenocortical tumorigenesis in mice and humans through insulinlike growth factor 2 and $\beta$-catenin. American Journal of Pathology 181 1017-1033. (https://doi.org/10.1016/j.ajpath.2012.05.026)

Heikkila M, Peltoketo H, Leppäluoto J, Ilves M, Vuolteenaho O \& Vainio S 2002 Wnt-4 deficiency alters mouse adrenal cortex function, reducing aldosterone production. Endocrinology 143 4358-4365. (https://doi.org/10.1210/en.2002-220275)

Hescot S, Amazit L, Lhomme M, Travers S, DuBow A, Battini S, Boulate G, Namer IJ, Lombes A, Kontush A, et al. 2017 Identifying mitotane-induced mitochondria-associated membranes dysfunctions: metabolomic and lipidomic approaches. Oncotarget 8 109924-109940. (https://doi.org/10.18632/oncotarget.18968)

Huang CCJ, Miyagawa S, Matsumaru D, Parker KL \& Yao HHC 2010 Progenitor cell expansion and organ size of mouse adrenal is regulated by Sonic hedgehog. Endocrinology 151 1119-1128. (https:// doi.org/10.1210/en.2009-0814)

Ilvesmäki V, Kahri AI, Miettinen PJ \& Voutilainen R 1993 Insulin-like growth factors (IGFs) and their receptors in adrenal tumors: high IGF-II expression in functional adrenocortical carcinomas. Journal of Clinical Endocrinology and Metabolism 77 852-858. (https://doi. org/10.1210/jcem.77.3.8370710)

Ingle DJ \& Higgins GM 1938 Autotransplantation and regeneration of the adrenal gland. Endocrinology 22 458-464. (https://doi. org/10.1210/endo-22-4-458)

Ip JCY, Pang TCY, Glover AR, Soon P, Zhao JT, Clarke S, Robinson BG, Gill AJ \& Sidhu SB 2015 Immunohistochemical validation of overexpressed genes identified by global expression microarrays in adrenocortical carcinoma reveals potential predictive and prognostic biomarkers. Oncologist 20 247-256. (https://doi.org/10.1634/ theoncologist.2014-0392)

Jouinot A, Assie G, Libe R, Fassnacht M, Papathomas T, Barreau O, de la Villeon B, Faillot S, Hamzaoui N, Neou M, et al. 2016 DNA methylation is an independent prognostic marker of survival in adrenocortical cancer. Journal of Clinical Endocrinology and Metabolism 102 923-932. (https://doi.org/10.1210/jc.2016-3205)

Juhlin CC, Goh G, Healy JM, Fonseca AL, Scholl UI, Stenman A, Kunstman JW, Brown TC, Overton JD, Mane SM, et al. 2015 Wholeexome sequencing characterizes the landscape of somatic mutations and copy number alterations in adrenocortical carcinoma. Journal of Clinical Endocrinology and Metabolism 100 E493-E502. (https://doi. org/10.1210/jc.2014-3282)

Kahn M 2014 Can we safely target the WNT pathway? Nature Reviews Drug Discovery 13 513-532. (https://doi.org/10.1038/nrd4233)

Kalari S \& Pfeifer GP 2010 Identification of Driver and Passenger DNA Methylation in Cancer by Epigenomic Analysis. Advanced Genetics 70 277-308. (https://doi.org/10.1016/B978-0-12-380866-0.60010-1)

Kebebew E, Reiff E, Duh QY, Clark OH \& McMillan A 2006 Extent of disease at presentation and outcome for adrenocortical carcinoma: have we made progress? World Journal of Surgery 30 872-878. (https://doi.org/10.1007/s00268-005-0329-x)

Kerkhofs TMA, Verhoeven RHA, Van der Zwan JM, Dieleman J, Kerstens MN, Links TP, Van de Poll-Franse L V. \& Haak HR 2013 Adrenocortical carcinoma: a population-based study on incidence and survival in the Netherlands since 1993. European Journal of Cancer 49 2579-2586. (https://doi.org/10.1016/j.ejca.2013.02.034)

Kerr SE, Thomas CB, Thibodeau SN, Ferber MJ \& Halling KC 2013 APC germline mutations in individuals being evaluated for familial adenomatous polyposis: a review of the mayo clinic experience with 1591 consecutive tests. Journal of Molecular Diagnostics 15 31-43. (https://doi.org/10.1016/j.jmoldx.2012.07.005)

Kim AC, Reuter AL, Zubair M, Else T, Serecky K, Bingham NC, Lavery GG, Parker KL \& Hammer GD 2008 Targeted disruption of beta-catenin in Sf1-expressing cells impairs development and 
maintenance of the adrenal cortex. Development 135 2593-2602. (https://doi.org/10.1242/dev.021493)

Kim Y, Lin Q, Zelterman D \& Yun Z 2009 Cell, tumor, and stem cell biology hypoxia-regulated delta-like 1 homologue enhances cancer cell stemness and tumorigenicity. Cancer Research 69 9271-9280. (https://doi.org/10.1158/0008-5472.CAN-09-1605)

Kim B, Song T-Y, Jung KY, Kim SG \& Cho E-J 2017 Direct interaction of menin leads to ubiquitin-proteasomal degradation of $\beta$-catenin. Biochemical and Biophysical Research Communications 492 128-134. (https://doi.org/10.1016/J.BBRC.2017.08.011)

King P, Paul A \& Laufer E 2009 Shh signaling regulates adrenocortical development and identifies progenitors of steroidogenic lineages. PNAS 106 21185-21190. (https://doi.org/10.1073/pnas.0909471106)

Kirschner LS, Carney JA, Pack SD, Taymans SE, Giatzakis C, Cho YS, Cho-Chung YS \& Stratakis CA 2000 Mutations of the gene encoding the protein kinase A type I-alpha regulatory subunit in patients with the Carney complex. Nature Genetics 26 89-92. (https://doi. org/10.1038/79238)

Kulis M \& Esteller M 20102 - DNA methylation and cancer. Advances in Genetics 70 27-56. (https://doi.org/10.1016/B978-0-12-380866$0.60002-2)$

Lalli E \& Luconi M 2018 The next step: mechanisms driving adrenocortical carcinoma metastasis. Endocrine-Related Cancer $\mathbf{2 5}$ R31-R48. (https://doi.org/10.1530/ERC-17-0440)

Leccia F, Batisse-Lignier M, Sahut-Barnola I, Val P, LefrançoisMartinez AM \& Martinez A 2016 Mouse models recapitulating human adrenocortical tumors: what is lacking? Frontiers in Endocrinology 7 93. (https://doi.org/10.3389/fendo.2016.00093)

Lerario AM, Worden FP, Ramm CA, Hasseltine EA, Stadler WM, Else T, Shah MH, Agamah E, Rao K \& Hammer GD 2014 The combination of insulin-like growth factor receptor 1 (IGF1R) antibody cixutumumab and mitotane as a first-line therapy for patients with recurrent/metastatic adrenocortical carcinoma: a multi-institutional NCI-sponsored trial. Hormones and Cancer 5 232-239. (https://doi. org/10.1007/s12672-014-0182-1)

Leroy B, Anderson M \& Soussi T 2014 TP53 mutations in human cancer: database reassessment and prospects for the next decade. Human Mutation 35 672-688. (https://doi.org/10.1002/humu.22552)

Li FP \& Fraumeni JF 1969 Rhabdomyosarcoma in children: epidemiologic study and identification of a familial cancer syndrome. Journal of the National Cancer Institute 43 1365-1373. (https://doi.org/10.1074/jbc.M606203200)

Li M, Squire JA \& Weksberg R 1997 Molecular genetics of BeckwithWiedemann syndrome. Current Opinion in Pediatrics 9 623-629. (https://doi.org/10.1097/00008480-199712000-00012)

Libe R, Groussin L, Tissier F, Elie C, Rene-Corail F, Fratticci A, Jullian E, Beck-Peccoz P, Bertagna X, Gicquel C, et al. 2007 Somatic TP53 mutations are relatively rare among adrenocortical cancers with the frequent $17 \mathrm{p} 13$ loss of heterozygosity. Clinical Cancer Research 13 844-850. (https://doi.org/10.1158/1078-0432.CCR-06-2085)

Lughezzani G, Sun M, Perrotte P, Jeldres C, Alasker A, Isbarn H, Budäus L, Shariat SF, Guazzoni G, Montorsi F, et al. 2010 The European Network for the Study of Adrenal Tumors staging system is prognostically superior to the international union against cancerstaging system: a North American validation. European Journal of Cancer 46 713-719. (https://doi.org/10.1016/j.ejca.2009.12.007)

Michalkiewicz E, Sandrini R, Figueiredo B, Miranda ECM, Caran E, Oliveira-Filho AG, Marques R, Pianovski MAD, Lacerda L, Cristofani LM, et al. 2004 Clinical and outcome characteristics of children with adrenocortical tumors: a report from the international pediatric adrenocortical tumor registry. Journal of Clinical Oncology 22 838-845. (https://doi.org/10.1200/JCO.2004.08.085)

Olivier M, Goldgar DE, Sodha N, Ohgaki H, Kleihues P, Hainaut P \& Eeles RA 2003 Li-Fraumeni and related syndromes: correlation between tumor type, family structure, and TP53 genotype. Cancer Research 63 6643-6650.
Ornitz DM \& Itoh N 2001 Fibroblast growth factors. Genome Biology 2 REVIEWS3005. (https://doi.org/10.1186/gb-2001-2-3-reviews3005)

Pacifico A \& Leone G 2007 Role of p53 and CDKN2A inactivation in human squamous cell carcinomas. Journal of Biomedicine \& Biotechnology 2007 43418. (https://doi.org/10.1155/2007/43418)

Papotti M, Libè R, Duregon E, Volante M, Bertherat J \& Tissier F 2011 The Weiss score and beyond-histopathology for adrenocortical carcinoma. Hormones and Cancer 2 333-340. (https://doi.org/10.1007/ s12672-011-0088-0)

Patterson EE, Holloway AK, Weng J, Fojo T \& Kebebew E 2011 MicroRNA profiling of adrenocortical tumors reveals miR-483 as a marker of malignancy. Cancer 117 1630-1639. (https://doi. org/10.1002/cncr.25724)

Pennanen M, Heiskanen I, Sane T, Remes S, Mustonen H, Haglund C \& Arola J 2015 Helsinki score - a novel model for prediction of metastases in adrenocortical carcinomas. Human Pathology $\mathbf{4 6}$ 404-410. (https://doi.org/10.1016/j.humpath.2014.11.015)

Pinto EM, Chen X, Easton J, Finkelstein D, Liu Z, Pounds S, RodriguezGalindo C, Lund TC, Mardis ER, Wilson RK, et al. 2015 Genomic landscape of paediatric adrenocortical tumours. Nature Communications 6 1-10. (https://doi.org/10.1038/ncomms7302)

Pinzani P, Scatena C, Salvianti F, Corsini E, Canu L, Poli G, Paglierani M, Piccini V, Pazzagli M, Nesi G, et al. 2013 Detection of circulating tumor cells in patients with adrenocortical carcinoma: a monocentric preliminary study. Journal of Clinical Endocrinology and Metabolism 98 3731-3738. (https://doi.org/10.1210/jc.2013-1396)

Pohlink C, Tannapfel A, Eichfeld U, Schmidt F, Führer D, Paschke R \& Koch CA 2004 Does tumor heterogeneity limit the use of the Weiss criteria in the evaluation of adrenocortical tumors? Journal of Endocrinological Investigation 27 565-569. (https://doi.org/10.1007/ BF03347480)

Ragazzon B, Libé R, Gaujoux S, Assié G, Fratticci A, Launay P, Clauser E, Bertagna X, Tissier F, de Reyniès A, et al. 2010 Transcriptome analysis reveals that p53 and \{beta\}-catenin alterations occur in a group of aggressive adrenocortical cancers. Cancer Research 70 8276-8281. (https://doi.org/10.1158/0008-5472.CAN-10-2014)

Rainey WE, Carr BR, Wang ZN \& Parker CR 2001 Gene profiling of human fetal and adult adrenals. Journal of Endocrinology $\mathbf{1 7 1}$ 209-215. (https://doi.org/10.1677/joe.0.1710209)

Rechache NS, Wang Y, Stevenson HS, Killian JK, Edelman DC, Merino M, Zhang L, Nilubol N, Stratakis CA, Meltzer PS, et al. 2012 DNA methylation profiling identifies global methylation differences and markers of adrenocortical tumors. Journal of Clinical Endocrinology and Metabolism 97 E1004-E1013. (https://doi. org/10.1210/jc.2011-3298)

Reincke M, Karl M, Travis WH, Mastorakos G, Allolio B, Linehan HM \& Chrousos GP 1994 p53 mutations in human adrenocortical neoplasms: immunohistochemical and molecular studies. Journal of Clinical Endocrinology and Metabolism 78 790-794. (https://doi. org/10.1210/jcem.78.3.8126158)

Ruggiero C, Doghman-Bouguerra M, Sbiera S, Sbiera I, Parsons M, Ragazzon B, Morin A, Robidel E, Favier J, Bertherat J, et al. 2017 Dosage-dependent regulation of VAV2 expression by steroidogenic factor-1 drives adrenocortical carcinoma cell invasion. Science Signaling 10 eaal2464. (https://doi.org/10.1126/scisignal.aal2464)

Sabolch A, Feng M, Griffith K, Hammer G, Doherty G \& Ben-Josef E 2011 Adjuvant and definitive radiotherapy for adrenocortical carcinoma. International Journal of Radiation Oncology Biology Physics 80 1477-1484. (https://doi.org/10.1016/j.ijrobp.2010.04.030)

Salvianti F, Canu L, Poli G, Armignacco R, Scatena C, Cantini G, Di Franco A, Gelmini S, Ercolino T, Pazzagli M, et al. 2017 New insights in the clinical and translational relevance of miR483-5p in adrenocortical cancer. Oncotarget 8 65525-65533. (https://doi. org/10.18632/oncotarget.19118)

Sbiera S, Schmull S, Assie G, Voelker HU, Kraus L, Beyer M, Ragazzon B, Beuschlein F, Willenberg HS, Hahner S, et al. 2010 High diagnostic 
and prognostic value of steroidogenic factor-1 expression in adrenal tumors. Journal of Clinical Endocrinology and Metabolism 95 E161-E171. (https://doi.org/10.1210/jc.2010-0653)

Sbiera S, Leich E, Liebisch G, Sbiera I, Schirbel A, Wiemer L, Matysik S, Eckhardt C, Gardill F, Gehl A, et al. 2015 Mitotane inhibits sterol-oAcyl transferase 1 triggering lipid-mediated endoplasmic reticulum stress and apoptosis in adrenocortical carcinoma cells. Endocrinology 156 3895-3908. (https://doi.org/10.1210/en.2015-1367)

Sbiera S, Sbiera I, Ruggiero C, Doghman-Bouguerra M, Korpershoek E, De Krijger RR, Ettaieb H, Haak H, Volante M, Papotti M, et al. 2017 Assessment of VAV2 expression refines prognostic prediction in adrenocortical carcinoma. Journal of Clinical Endocrinology and Metabolism 102 3491-3498. (https://doi.org/10.1210/jc.2017-00984)

Shaikh LH, Zhou J, Teo AED, Garg S, Neogi SG, Figg N, Yeo GS, Yu H, Maguire JJ, Zhao W, et al. 2015 LGR5 activates noncanonical Wnt signaling and inhibits aldosterone production in the human adrenal. Journal of Clinical Endocrinology and Metabolism 100 E836-E844. (https://doi.org/10.1210/jc.2015-1734)

Sidhu S, Martin E, Gicquel C, Melki J, Clark SJ, Campbell P, Magarey CJ, Schulte KM, Röher HD, Delbridge L, et al. 2005 Mutation and methylation analysis of TP53 in adrenal carcinogenesis. European Journal of Surgical Oncology 31 549-554. (https://doi.org/10.1016/j. ejso.2005.01.013)

Soon PSH, Tacon LJ, Gill AJ, Bambach CP, Sywak MS, Campbell PR, Yeh MW, Wong SG, Clifton-Bligh RJ, Robinson BG, et al. 2009 miR195 and miR-483-5p identified as predictors of poor prognosis in adrenocortical cancer. Clinical Cancer Research 15 7684-7692. (https://doi.org/10.1158/1078-0432.CCR-09-1587)

Terzolo M, Angeli A, Fassnacht M, Daffara F, Tauchmanova L, Conton PA, Rossetto R, Buci L, Sperone P, Grossrubatscher E, et al. 2007 Adjuvant mitotane treatment for adrenocortical carcinoma. New England Journal of Medicine 356 2372-2380. (https://doi. org/10.1056/NEJMoa063360)

Vatrano S, Volante M, Duregon E, Giorcelli J, Izzo S, Rapa I, Votta A, Germano A, Scagliotti G, Berruti A, et al. 2018 Detailed genomic characterization identifies high heterogeneity and histotype-specific genomic profiles in adrenocortical carcinomas. Modern Pathology 31 1257-12691. (https://doi.org/10.1038/s41379-018-0042-6)

Vidal V, Sacco S, Rocha AS, Da Silva F, Panzolini C, Dumontet T, Doan TMP, Shan J, Rak-Raszewska A, Bird T, et al. 2016 The adrenal capsule is a signaling center controlling cell renewal and zonation through Rspo3. Genes and Development 30 1389-1394. (https://doi. org/10.1101/gad.277756.116)

Vinson GP 2003 Adrenocortical zonation and ACTH. Microscopy Research and Technique 61 227-239. (https://doi.org/10.1002/jemt.10331)

Wajchenberg BL, Albergaria Pereira MA, Medonca BB, Latronico AC, Carneiro PC, Ferreira Alves VA, Zerbini MCN, Liberman B, Gomes GC \& Kirschner MA 2000 Adrenocortical carcinoma.
Cancer 88 711-736. (https://doi.org/10.1002/(SICI)10970142(20000215)88:4<711::AID-CNCR1>3.0.CO;2-W)

Walczak EM \& Hammer GD 2015 Regulation of the adrenocortical stem cell niche: implications for disease. Nature Reviews Endocrinology 11 14-28. (https://doi.org/10.1038/nrendo.2014.166)

Walczak EM, Kuick R, Finco I, Bohin N, Hrycaj SM, Wellik DM \& Hammer GD 2014 Wnt signaling inhibits adrenal steroidogenesis by cell-autonomous and non-cell-autonomous mechanisms. Molecular Endocrinology 28 1471-1486. (https://doi.org/10.1210/ me.2014-1060)

Wasserman JD, Novokmet A, Eichler-Jonsson C, Ribeiro RC, RodriguezGalindo C, Zambetti GP \& Malkin D 2015 Prevalence and functional consequence of TP53 mutations in pediatric adrenocortical carcinoma: a children's oncology group study. Journal of Clinical Oncology 33 602-609. (https://doi.org/10.1200/JCO.2013.52.6863)

Weber MM, Fottner C, Schmidt P, Brodowski KMH, Gittner K, Lahm H, Engelhardt D \& Wolf E 1999 Postnatal overexpression of insulin-like growth factor II in transgenic mice is associated with adrenocortical hyperplasia and enhanced steroidogenesis. Endocrinology 140 1537-1543. (https://doi.org/10.1210/en.140.4.1537)

Weiss LM 1984 Comparative histologic study of 43 metastasizing and nonmetastasizing adrenocortical tumors. American Journal of Surgical Pathology 8 163-169. (https://doi.org/10.1097/00000478-19840300000001)

West AN, Neale GA, Pounds S, Figueredo BC, Rodriguez Galindo C, Pianovski MAD, Oliveira Filho AG, Malkin D, Lalli E, Ribeiro R, et al. 2007 Gene expression profiling of childhood adrenocortical tumors. Cancer Research 67 600-608. (https://doi.org/10.1158/0008-5472. CAN-06-3767)

Wieneke JA, Thompson LDR \& Heffess CS 2003 Adrenal cortical neoplasms in the pediatric population: a clinicopathologic and immunophenotypic analysis of 83 patients. American Journal of Surgical Pathology 27 867-881. (https://doi.org/10.1097/00000478200307000-00001)

Wu X \& Hua X 2008 Menin, histone h3 methyltransferases, and regulation of cell proliferation: current knowledge and perspective. Current Molecular Medicine 8 805-815. (https://doi.org/10.1016/j. bbi.2008.05.010)

Zebisch M, Xu Y, Krastev C, Macdonald BT, Chen M, Gilbert RJC, He X \& Jones EY 2013 Structural and molecular basis of ZNRF3/RNF43 transmembrane ubiquitin ligase inhibition by the Wnt agonist R-spondin. Nature Communications 4 2787. (https://doi.org/10.1038/ ncomms3787)

Zheng S, Cherniack AD, Dewal N, Moffitt RA, Danilova L, Murray BA, Lerario AM, Else T, Knijnenburg TA, Ciriello G, et al. 2016 Comprehensive pan-genomic characterization of adrenocortical carcinoma. Cancer Cell 29 723-736. (https://doi.org/10.1016/j. ccell.2016.04.002)

Received in final form 17 July 2018

Accepted 2 August 2018

Accepted Preprint published online 2 August 2018 (c) 2019 Society for Endocrinology Published by Bioscientifica Ltd. Printed in Great Britain 